\title{
Cinematographic analysis of bovine embryo development in serum-free oviduct-conditioned medium
}

\author{
B. Grisart, A. Massip and F. Dessy* \\ Université Catholique de Louvain, Unité des Sciences Vétérinaires, Louvain-la-Neuve, Belgium
}

\begin{abstract}
Development of bovine embryos produced in vitro from the one-cell to the blastocyst stage in serum-free oviduct-conditioned medium was investigated for 8 days consecutively by time-lapse cinematography. Three movies were analysed (130 embryos). The following observations were made. (1) Development under cine-recording conditions was similar to that in a classical incubator. (2) The highest proportion of embryos at the two-cell, three-four-cell, five-eight-cell, 9-16-cell, morula and blastocyst stages were recorded at 34, $46,61,115,149$ and $192 \mathrm{~h}$ after insemination, respectively. Cleavage asynchrony between blastomeres within individual embryos started at the two-cell stage. (3) The duration of the first three cell cycles was $35 \mathrm{~h}, 14 \mathrm{~h}$ and $11-62 \mathrm{~h}$, respectively. (4) Detailed analysis of 13 embryos revealed that developmental arrest ('Lag-phase') occurred at the four-cell ( 1 of 13 ), five-cell ( 2 of 13), six-cell ( 3 of 13), seven-cell ( 3 of 13) or eight-cell stage (4 of 13); this phase lasted about $59 \mathrm{~h}$. Embryos arrested at the eight-cell stage developed into morula-blastocysts ( 3 of 4 ) at a higher rate than did those arrested at earlier stages ( 2 of 9). (5) The faster the embryos cleaved into early stages (two-cell, three-four-cell and five-eight-cell), the higher the probability that they developed into morula-blastocyst: $70 \%$ of the embryos reaching the two-cell stage before $30-31 \mathrm{~h}$ after insemination developed into morula-blastocyst. We suggest that the lag-phase as well as the link between early cleavage kinetics and further development could be related to the transcriptional activity of the embryo at about the 5-8-cell stage.
\end{abstract}

\section{Introduction}

In vitro methodology to obtain large numbers of bovine embryos is routinely used, and even on an industrial scale to produce beef embryos of desired genetic quality (Gordon, 1991; Lu and Polge, 1992). This method is also an excellent tool for fundamental investigations of early embryo development. In this respect much work remains to be done in livestock species such as cattle. At least three critical stages in embryo development can be influenced by culture conditions: (1) the transition from maternal to zygotic control of development; (2) compaction at the morula stage; and (3) blastocyst formation. Serum-free oviduct-conditioned media support development from the one-cell to the blastocyst stage (Mermillod et al., 1992a, b, 1993).

An accurate study of the timing of embryo development in this kind of media would provide interesting information on preimplantation features, such as cell-cycle duration and the lengthening of the cell cycle at the time when genomic expression resumes.

Few reports have been published on cleavage kinetics of bovine embryos produced in vitro (Sirard and Lambert, 1985; First and Barnes, 1989; Pollard et al., 1991; Barnes and First,

*Correspondence: Unité Vétérinaire, Place Croix du Sud 3, B-1348 Louvainla-Neuve, Belgium.

Received 6 July 1993.
1991; Van Soom et al., 1992) because these investigations require frequent observations out of the incubator and could affect normal embryo development. The only way to obtain accurate data is by continuous cinematographic recording of embryos in culture. This method has been used previously to observe cow embryos harvested in vivo (Massip and Mulnard, 1980; Massip et al., 1982, 1983a, b).

In the present study time-lapse cinematography was used to analyse the behaviour of embryos cultured in serum-free oviduct-conditioned medium. The aim was to obtain information on the developmental characteristics of individual embryos and thus to establish a correlation between the early behaviour of an embryo and its further development in vitro.

\section{Materials and Methods}

Source of embryos and culture

Embryos were produced by in vitro maturation and in vitro fertilization of oocytes from ovaries of slaughtered cows, according to the method described by Mermillod et al. (1992b). Intact cumulus-oocyte complexes were matured in tissue culture medium 199 plus $10 \%$ heat-treated fetal calf serum supplemented with $0.5 \mu \mathrm{g}$ pure pig $\mathrm{FSH} \mathrm{ml}{ }^{-1}, 5 \mu \mathrm{g}$ pure pig $\mathrm{LH} \mathrm{ml}{ }^{-1}$ (Beckers, 1987) and $1 \mu \mathrm{g}$ oestradiol $\mathrm{ml}^{-1}$ (Sigma Chemical Company, St Louis, MO). One hundred complexes 
were placed in $500 \mu \mathrm{l}$ of this medium in four-well plates (Nunc, Roskilde). After $24 \mathrm{~h}$ at $39^{\circ} \mathrm{C}$ in a humidified atmosphere containing $5 \% \quad \mathrm{CO}_{2}$, cumulus-oocyte complexes with expanded cumulus masses were transferred to fertilization medium in four-well plates.

This medium consisted of modified Tyrode's medium supplemented with $6 \mathrm{mg}$ fatty-acid-free $\mathrm{BSA} \mathrm{ml}{ }^{-1}, 4 \mathrm{mg}$ sodium lactate $\mathrm{ml}^{-1}, 0.11 \mathrm{mg}$ sodium pyruvate $\mathrm{ml}^{-1}$ (Sigma Chemical Company) (TALP) and $10 \mu \mathrm{g}$ heparin $\mathrm{ml}^{-1}$ (Calbiochem, San Diego, CA). To each $500 \mu \mathrm{l}$ of fertilization medium $2 \times 10^{6}$ spermatozoa, separated using Percoll (Pharmacia, Uppsala), were added. The same ejaculate from one Belgian Blue bull was used throughout the experiments. Cumulus-oocyte complexes were removed from the fertilization medium after $18 \mathrm{~h}$, and oocytes were denuded from cumulus cells by vortexing at medium speed for $2 \mathrm{~min}$. About 100 ova were handled together in $2 \mathrm{ml}$ PBS containing $0.25 \%$ trypsin (Gibco BRL, Paisley). Only zygotes that were completely cumulus-free were placed in culture. This was to avoid possible depletion of the culture medium by granulosa cells.

After washing in medium 199, naked zygotes were cultured at $39^{\circ} \mathrm{C}$ in droplets (50 embryos per $50 \mu \mathrm{l}$ ) of serum-free oviduct-conditioned medium (Mermillod et al, 1992a, 1993) under mineral oil in a humidified atmosphere containing 5\% $\mathrm{CO}_{2}$. The culture was run for 8 days in the same drop of conditioned medium without replenishing the media.

\section{Time-lapse cinematographic equipment}

A Plexiglas thermoregulated box $(60 \mathrm{~cm} \times 35 \mathrm{~cm} \times 50 \mathrm{~cm})$ was adapted to fit onto an inverted microscope (Nikon Diaphot, Tokyo). A contact thermometer located close to the cinematographic chamber controlled a domestic hair-dryer and maintained an internal temperature of $39^{\circ} \mathrm{C}$. A cinematographic chamber placed on the microscope plate was built by first boring a hole, $6.5 \mathrm{~cm}$ in diameter, into a Plexiglas sheet $2 \mathrm{~cm}$ thick. A bottom sheet $2 \mathrm{~mm}$ thick was glued into place; a sheet $6 \mathrm{~mm}$ thick was screwed with thumb screws onto the top; and the entire structure secured by a gasket. Embryos were cultured in a tissue culture dish $3.5 \mathrm{~cm}$ in diameter (Falcon 3080, Becton Dickinson, Erembodegem) placed directly inside the closed cinematographic chamber. A $5 \% \mathrm{CO}_{2}: 95 \%$ air mixture was humidified and warmed by passing it through sterile water at $39^{\circ} \mathrm{C}$ in a gas bubbler bottle and flushed into the chamber for $15 \mathrm{~min}$ every $30 \mathrm{~min}$. The culture was run for 8-10 days without changing the medium.

A Bolex $16 \mathrm{~mm}$ cine-camera controlled by a time-lapse system exposed a single frame every minute. The microscope light was switched on a few seconds before and switched off immediately after. The experiment was carried out in a dark room. Video copies of each movie were prepared and every picture was numbered according to the length of time the embryos had been in culture.

\section{Experimental protocol}

After fertilization and removal of the granulosa cells, one group of zygotes was cultured in the cinematographic chamber, and a simultaneous control group in a classical incubator. The day culture began was day 0 . On day 2 , rates of cleavage and of formation of five-eight-cell embryos were recorded for both groups. The rates of formation of blastocysts on days 6, 7 and 8 were also recorded for both groups.

Three movies were performed, one at $10 \times$ magnification (movie 416) and two at $5 \times$ magnification (movies 477 and 483). The higher magnification was used to obtain more accurate data on each embryo (for example cleavage rate and exact number of cells). The same batch of conditioned medium was used throughout.

\section{Statistical analysis}

Chi-square analysis $(P<0.05)$ was used to compare the number of embryos at different stages. ANOVA 1 was used to compare mean cleavage time.

\section{Results}

\section{Validity of the time-lapse analysis method}

A total of 250 zygotes were cultured, 111 in the incubator and 139 in the cinematographic chamber. However, only 130 of the zygotes in the chamber were analysed because some embryos shifted out of the field of the cine-camera in movie 416. The number of embryos reaching the two-four-cell and five-eight-cell stage after 2 days of culture, and the cumulative number of blastocysts on days 6,7 and 8 were recorded in both groups (Table 1).

On day $2,37-74 \%$ of embryos were at the five-eight cell stage in the cinematographic chamber, compared with $41-55 \%$ in the incubator. The proportion of blastocysts at day 8 varied from 15 to $21 \%$ under the camera versus 17 to $24 \%$ in the incubator. No significant difference $(P>0.05)$ between control and experimental groups was observed at any stage of the three movies. The rates of formation of five-eight-cell stage embryos on day 2 and of blastocysts on days 6,7 and 8 did not differ significantly from one movie to another in the control group (I) or in the experimental (C) group.

\section{Kinetics of development}

Distribution of cleavage divisions. The distribution of embryos at each developmental stage during the culture period is shown (Fig. 1). The distribution curves overlap and the progressive decrease of the height of the peak for the successive stages indicates the progressive block of embryo development. The curve for the five-eight-cell stage (Fig. Ic) is characterized by a plateau and a slow decline. It is followed at the 9-16-cell stage by an important decrease in the peak distribution in relation to the well-known block after the five-eight-cell stage.

The morphology of the corresponding stages, at the time when they occurred most often, is illustrated in Fig. 2. The time between the first appearance of a given stage and its peak occurrence increases with the successive stages (as do the SDs) (Table 2). This reflects an increasing asynchrony of cleavages from the two-cell stage onwards; intermediate three-cell stages were noted for $4 \mathrm{~min}$ to more than $4 \mathrm{~h}$. 
Table 1. Development of bovine embryos fertilized in vitro cultured either in an incubator (I) or under cine-record (C)

\begin{tabular}{|c|c|c|c|c|c|c|c|}
\hline \multirow[b]{2}{*}{ Movie } & \multirow[b]{2}{*}{ Group } & \multirow[b]{2}{*}{$n$} & \multicolumn{2}{|c|}{ Day $2^{\mathrm{a}}$} & \multirow[t]{2}{*}{ Day 6} & \multirow{2}{*}{$\begin{array}{c}\text { Day } 7 \\
\begin{array}{c}\text { Blastocysts } \\
n(\%)\end{array}\end{array}$} & \multirow[t]{2}{*}{ Day 8} \\
\hline & & & $\begin{array}{c}\text { Cleaved } \\
n(\%)\end{array}$ & $\begin{array}{c}\text { 5-8-cell } \\
n(\%)\end{array}$ & & & \\
\hline \multirow[t]{2}{*}{416} & I1 & 29 & $26(90)$ & $16(55)$ & $3(10)$ & $5(17)$ & $5(17)$ \\
\hline & $\mathrm{C} 1$ & 27 & $24(89)$ & $20(74)$ & 1 & $3(11)$ & $4(15)$ \\
\hline \multirow[t]{2}{*}{477} & I2 & 38 & $27(71)$ & $16(42)$ & 4 (II) & $8(21)$ & $9(24)$ \\
\hline & $\mathrm{C} 2$ & 53 & $38(72)$ & $31(58)$ & $2 \quad(4)$ & $8(15)$ & II (21) \\
\hline \multirow[t]{2}{*}{483} & $\mathrm{I} 3$ & 44 & $25(51)$ & $18(41)$ & $4 \quad(9)$ & $9(2 \mathrm{I})$ & $9(21)$ \\
\hline & C3 & 59 & $36(61)$ & $22(37)$ & $5 \quad(8)$ & $10(17)$ & $11(19)$ \\
\hline
\end{tabular}

${ }^{a}$ Number and percentage (within parentheses) of cleaved embryos and embryos at the 5-8-cell stage at day 2 under cine-record and in the control group for the

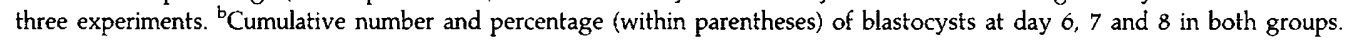

Duration of the cell cycles. The mean duration of the first three cell cycles was calculated in movie 416 by measuring the time taken by each embryo to double its number of cells. The first cell cycle lasted (mean $\pm \mathrm{SD}$ ) about $34 \mathrm{~h} 23 \mathrm{~min} \pm$ $6 \mathrm{~h} 50 \mathrm{~min}(n=13)$ and the second cycle $13 \mathrm{~h} 35 \mathrm{~min} \pm$ $2 \mathrm{~h} 3 \mathrm{~min}(n=13)$. The duration of the third cycle was $11 \mathrm{~h} 5 \mathrm{~min} \pm 3 \mathrm{~h} 17 \mathrm{~min}$ or $62 \mathrm{~h} 37 \mathrm{~min} \pm 19 \mathrm{~h} 36 \mathrm{~min}$, depending on whether the embryo reached the eight-cell stage before $(n=4)$ or after $(n=6)$ the developmental arrest observed between the five-cell and eight-cell stage (see below).

Developmental arrest at early cleavage stages. It was observed in all three movies that the development of most of the cleaving embryos stopped for some time during the third cell cycle, that is, between the four-cell and eight-cell stage. In movie $\mathbf{4 1 6}$ we were able to determine the exact number of cells for each embryo entering this developmental arrest. This phenomenon, termed 'lag-phase', was taken to occur when the interval between two mitoses within the third cell cycle was twice as long as the duration of the second cell cycle, that is, $28 \mathrm{~h}(2 \times 14 \mathrm{~h})$. This type of behaviour was observed for nearly all of the embryos. In movie 416 we recorded accurately at which stage each embryo enters its lag-phase, duration of the lag-phase and the stage of embryo development at day 8 (Table 3).

In spite of the small number of embryos studied $(n=13)$ some observations are noteworthy. (1) The three blastocysts that appear in movie 416 originated from embryos entering the lag-phase at the six-cell, seven-cell and eight-cell stage. (2) A high proportion (3 of 4 versus 2 of 9) of morulae and blastocysts developed from embryos exhibiting a lag-phase at the eight-cell stage. (3) Embryos arrested at earlier stages (four-cell and five-cell stage) cleaved at a slower rate than did those arrested at more advanced stages (six-cell, seven-cell and eight-cell stages), and did not develop into morulae or blastocysts. This suggests that the slower the embryos cleave, the less chance they have of developing to these late stages.

After their developmental arrest, nearly all the embryos ( 12 of 13) resumed division. At the end of the culture period (day 8 ) one embryo $(8 \%)$ was at the four-cell stage, two $(15 \%)$ at the five-cell stage, two $(15 \%)$ at the seven-cell stage, three $(23 \%)$ at
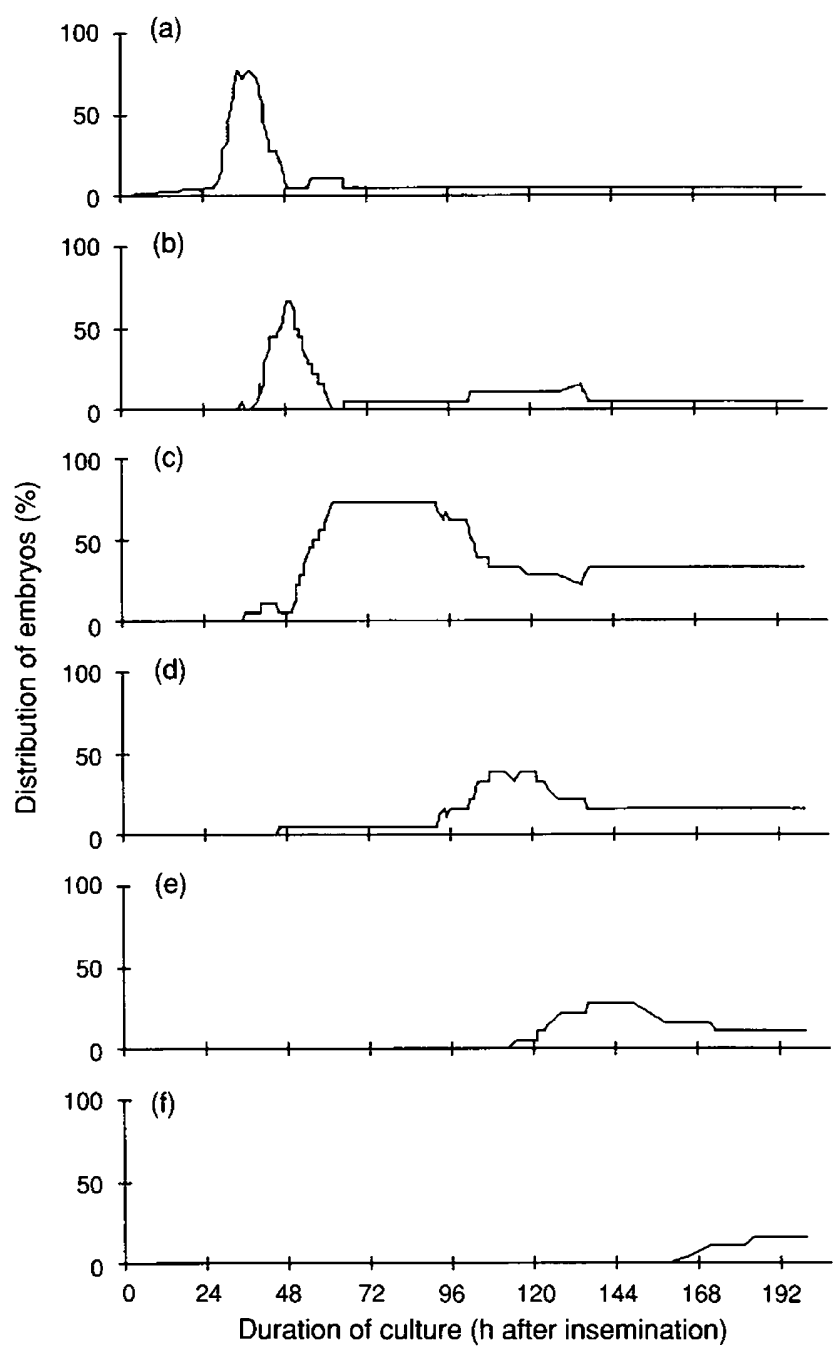

Fig. 1. Distribution (percentage) of cleaved bovine embryos during culture under cine-record (data from movie 416; $n=18$ ). Proportion of (a) two-cell embryos, (b) three-four-cell embryos, (c) five-eight-cell embryos, (d) 9-16-cell embryos, (e) morulae and (f) blastocysts during culture are shown. 

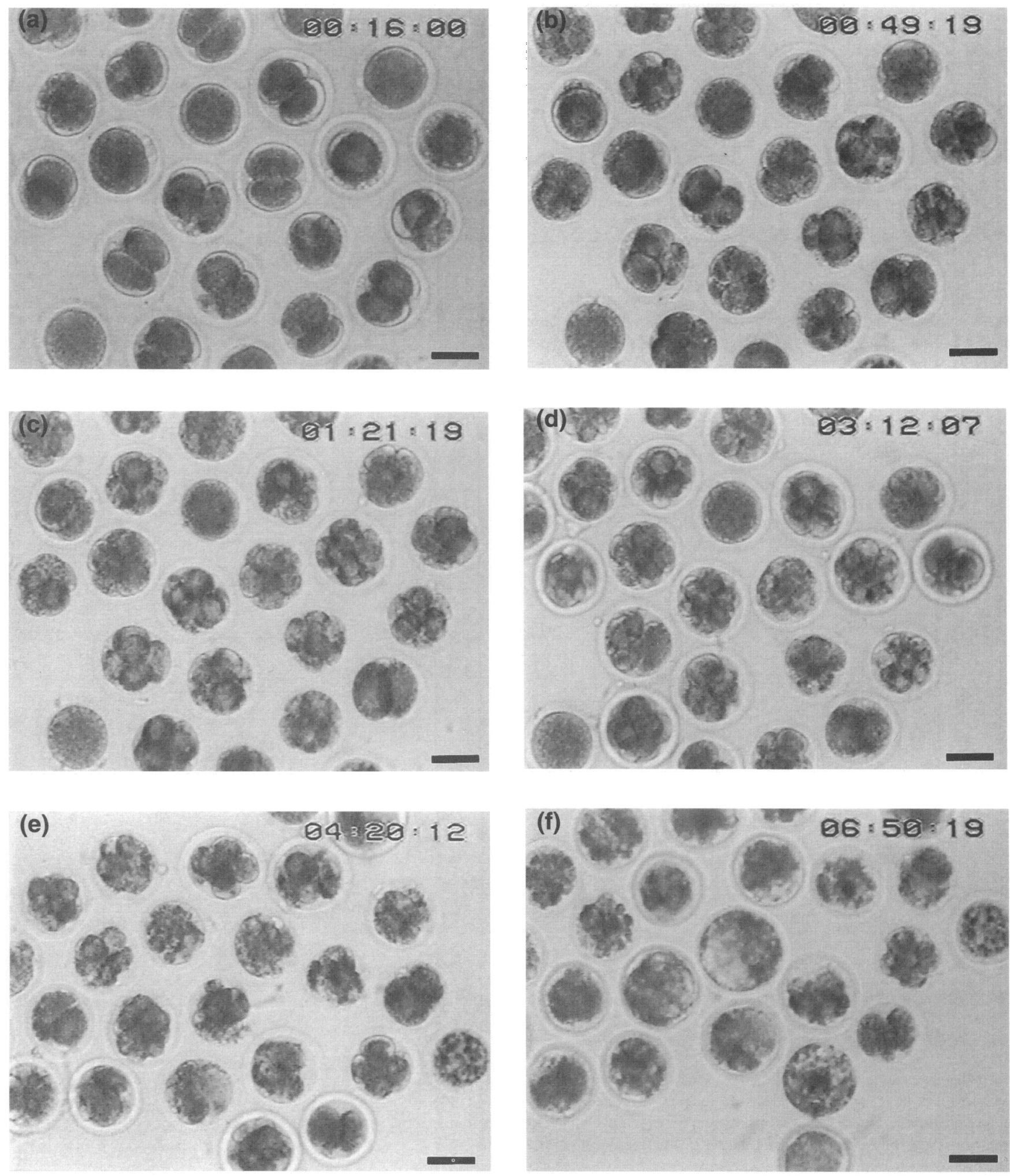

Fig. 2. Pictures from movie 416 taken at the time of peak emergence of (a) two-cell bovine embryos, (b) three-four-cell embryos, (c) five-eight-ceil embryos, (d) 9-16-cell embryos, (e) morulae and (f) blastocysts. (Scale bars represent $100 \mu \mathrm{m}$.) 
Table 2. Time of first appearance and time of peak emergence of early cleavage stages of bovine embryos under cine-recording

\begin{tabular}{lcc}
\hline Stage & $\begin{array}{c}\text { Time of first } \\
\text { appearance }\end{array}$ & $\begin{array}{c}\text { Time of peak } \\
\text { emergence }\end{array}$ \\
\hline
\end{tabular}

Two-cell

Three-four-cell

Five-eight-cell

9-16-cell

Morula

Blastocyst
$26 \mathrm{~h} 11 \mathrm{~min} \pm 01 \mathrm{~h} 24 \mathrm{~min}$

$31 \mathrm{~h} 17 \mathrm{~min} \pm 03 \mathrm{~h} 36 \mathrm{~min}$

$36 \mathrm{~h} 44 \mathrm{~min} \pm 00 \mathrm{~h} 59 \mathrm{~min}$

$59 \mathrm{~h} 31 \mathrm{~min} \pm 13 \mathrm{~h}$ II min

$119 \mathrm{~h} 15 \mathrm{~min} \pm 08 \mathrm{~h} 02 \mathrm{~min}$

$159 \mathrm{~h} 13 \mathrm{~min} \pm 06 \mathrm{~h} 06 \mathrm{~min}$
$33 \mathrm{~h} 54 \mathrm{~min} \pm 00 \mathrm{~h} 35 \mathrm{~min}$

$45 \mathrm{~h} 28 \mathrm{~min} \pm 03 \mathrm{~h} 31 \mathrm{~min}$

$61 \mathrm{~h} 03 \mathrm{~min} \pm 05 \mathrm{~h} 42 \mathrm{~min}$

$115 \mathrm{~h} 03 \mathrm{~min} \pm 15 \mathrm{~h} 02 \mathrm{~min}$

$148 \mathrm{~h} 34 \mathrm{~min} \pm 13 \mathrm{~h} 48 \mathrm{~min}$

$192 \mathrm{~h} 07 \mathrm{~min} \pm 12 \mathrm{~h} 26 \mathrm{~min}$

Values are means $\pm \mathrm{SD}$ of time after insemination; results are from the three movies representing a total of 130 embryos.

Table 3. Time and duration of the "lag-phase'a and stage reached by day 8 , according to the stage at which the phase begins in bovine embryos

\begin{tabular}{|c|c|c|c|c|c|}
\hline \multirow[b]{2}{*}{ Stage at start of phase } & \multicolumn{3}{|c|}{ 'Lag-phase' } & \multicolumn{2}{|c|}{ Stage at day 8} \\
\hline & $n$ & Start & Duration & Morulae & Blastocysts \\
\hline Four-cell & 1 & $68 \mathrm{~h} 48 \mathrm{~min}$ & $66 \mathrm{~h} 18 \mathrm{~min}$ & $0 / 1$ & $0 / 1$ \\
\hline Five-cell & 2 & $64 \mathrm{~h} 48 \mathrm{~min} \pm 06 \mathrm{~h} 29 \mathrm{~min}$ & 36 h $57 \mathrm{~min} \pm 04$ h $57 \mathrm{~min}$ & $0 / 2$ & $0 / 2$ \\
\hline Six-cell & 3 & $55 \mathrm{~h} 48 \mathrm{~min} \pm 02 \mathrm{~h} 57 \mathrm{~min}$ & $46 \mathrm{~h} 06 \mathrm{~min} \pm 03 \mathrm{~h} 53 \mathrm{~min}$ & $0 / 3$ & $1 / 3$ \\
\hline Seven-cell & 3 & $61 \mathrm{~h} 27 \min \pm 3 \mathrm{~h} 47 \mathrm{~min}$ & $53 \mathrm{~h} 02 \mathrm{~min} \pm 27 \mathrm{~h} 53 \mathrm{~min}$ & $0 / 3$ & $1 / 3$ \\
\hline Eight-cell & 4 & 59 h $42 \min \pm 03$ h $33 \mathrm{~min}$ & $42 \mathrm{~h} 29 \min \pm 06 \mathrm{~h} 58 \mathrm{~min}$ & $2 / 4$ & $1 / 4$ \\
\hline Total & 13 & & & $2 / 13$ & $3 / 13$ \\
\hline Mean & & 59 h $14 \mathrm{~min} \pm 06 \mathrm{~h} 16 \mathrm{~min}$ & $46 \mathrm{~h} 47 \mathrm{~min} \pm 15 \mathrm{~h} 06 \mathrm{~min}$ & & \\
\hline
\end{tabular}

a'Lag-phase': developmental arrest observed within the third cell cycle. Arbitrarily, a lag-phase is present when the time between two mitoses of the third cell cycle exceeds twice the duration of the preceding cell cycle (second cell cycle), that is, $28 \mathrm{~h}(2 \times 14 \mathrm{~h})$.

Values are means \pm SD of time after insemination; results are from 13 embryos studied in movie 416 .

the $8-16$-cell stage, two $(15 \%)$ at the morula and three $(23 \%)$ at the blastocyst stage.

The lag-phase was also observed in movies 477 and 483 and its duration was of the same order of duration $(55 \mathrm{~h})$. However, at the low magnification used in movies 477 and 483 , it was not possible to detect the exact stage of development at which it occurred.

\section{Relationships between early cleavage kinetics and further development of embryos}

In movies 477 and 483 the earliest time of appearance of the early cleavage stages (two-cell, three-four-cell, five-eight-cell stages) was noted, as well as the stage reached by each of them at day 8 . Only cleaved embryos were taken into account. They were classified into three groups: embryos reaching morulablastocyst (group 1), embryos reaching the 9-16-cell stage (group 2) and embryos reaching a stage where they had less than nine cells (group 3). In each of these groups, the time at which they cleaved into the two-cell, three-four-cell or fiveeight-cell stage was recorded. Embryos that had developed into morula-blastocysts by day 8 cleaved earlier at the two-cell, three-four-cell and five-eight-cell stage than did those that had developed to no more than the nine-cell stage (ANOVA 1)
(Table 4). However, no statistical difference could be observed between embryos reaching the 9-16-cell stage (group 2) and those becoming morulae-blastocysts at day 8 (group 1 ).

In Fig. 3a the time during which two-cell embryos appeared was arbitrarily divided into ten equal intervals. The developmental stage reached by day 8 is related to the kinetics of cleavage at the two-cell stage: the embryos that cleave the fastest are on the left and the slowest are on the right. A similar analysis was carried out using the time at which three-fourcell embryos (Fig. 3b) and five-eight-cell embryos (Fig. 3c) appear.

The first embryos to cleave give a higher rate of morulablastocyst formation than do the slowest ones (Fig. 3). This is particularly obvious at the two-cell stage and at the three-fourcell stage. More than $70 \%$ of the embryos that had reached the two-cell stage before $30-31 \mathrm{~h}$ after insemination were morulablastocysts by day 8 . This proportion was significantly higher $\left(\chi^{2} ; P<0.05\right)$ than that calculated for embryos that reached the two-cell stage later (more than $31 \mathrm{~h}$ after insemination).

\section{Discussion}

The study reported here shows that bovine embryos matured and fertilized in vitro and then cultured in the conditions used 
Table 4. Comparison of the time at which embryos cleaved into two cells, three-four cells or five-eight cells, according to the developmental stage they had reached at day 8 (morula-blastocyst, 9-16-cell stage or a stage < nine-cell)

\begin{tabular}{|c|c|c|c|}
\hline & \multicolumn{3}{|c|}{ Stage reached at day 8} \\
\hline & Morula-blastocyst & 9-16-cell stage & $<$ Nine-cell stage \\
\hline Two-cell stage & $30 \mathrm{~h} 05 \mathrm{~min} \pm 05 \mathrm{~h} 23 \mathrm{~min}^{\mathrm{a}}$ & $30 \mathrm{~h} 51 \mathrm{~min} \pm 03 \mathrm{~h} 31 \mathrm{~min}^{\mathrm{a}}$ & $36 \mathrm{~h} 38 \mathrm{~min} \pm 05 \mathrm{~h} 23 \mathrm{~min}^{\mathrm{b}}$ \\
\hline Three-four-cell stage & $37 \mathrm{~h} 16 \min \pm 04 \mathrm{~h} 16 \min ^{\mathrm{a}}$ & $36 \mathrm{~h} 49 \mathrm{~min} \pm 03 \mathrm{~h} 52 \mathrm{~min}^{\mathrm{a}}$ & $46 \mathrm{~h} 29 \mathrm{~min} \pm 11 \mathrm{~h} 05 \mathrm{~min}^{\mathrm{b}}$ \\
\hline Five-eight-cell stage & $48 \mathrm{~h} 01 \mathrm{~min} \pm 05 \mathrm{~h} 56 \mathrm{~min}^{\mathrm{a}}$ & $47 \mathrm{~h} 28 \mathrm{~min} \pm 05 \mathrm{~h} 37 \mathrm{~min}^{\mathrm{a}}$ & $54 \mathrm{~h} 05 \mathrm{~min} \pm 07 \mathrm{~h} 08 \mathrm{~min}^{\mathrm{b}}$ \\
\hline
\end{tabular}

Values are means \pm SD of time after insemination; results are from two-cell stage $(n=69)$, three-four-cell stage $(n=69)$ and five-eight-cell stage $(n=58)$ embryos from movies 477 and 483.

Values within the same row with different superscripts are significantly different (ANOVA 1).

for cinematography develop at the same rate as do control embryos placed in serum-free oviduct-conditioned medium. The cinematographic method, therefore, is a good tool for analysis of the kinetics of development and behaviour of embryos in vitro. This method has already proved useful in investigating the behaviour of mouse embryos (Mulnard, 1967), hamster and rhesus monkey embryos (Bavister, 1988) and cow blastocysts produced in vivo (Massip and Mulnard, 1980; Massip et al., 1982, 1983a, b).

The timing of cleavages is in the range reported by First and Barnes (1989); Pollard et al. (1991) and Van Soom et al. (1992). A comparison with development in vivo is difficult because of variations in the time of ovulation and in the subsequent fertilization. It is generally recognized that in bovine embryos produced in vitro development is slower than in those that develop in vivo, especially after the eight-cell stage has been reached (Barnes and Eyestone, 1990). This is also the case in mice (Bowman and McLaren, 1970). Our results are in agreement with these observations, as the delay in appearance of 9-16-cell embryos, morulae and blastocysts is about $30-40 \mathrm{~h}$ when compared with embryos produced in vivo (Thibault, 1966; McGaugh et al., 1974; Prather and First, 1988). However, our data correspond to those of Hamilton and Laing (1946) on non-superovulated embryos recovered in vivo. Thus, caution is recommended when data obtained from in vitro and in vivo studies are compared, as the accuracy of cleavage analysis in vivo is about $\pm 24 \mathrm{~h}$. Moreover, such comparisons do not take into account the fact that blastocysts in vitro often have significantly fewer cells (Iwasaki et al., 1990), so that the developmental rate is probably slower than it appears by morphological evaluation.

The most unusual finding in our movies was certainly the developmental arrest ('lag-phase') observed at the four-cell stage but mainly at the five-cell, six-cell, seven-cell or eight-cell stages. This phenomenon was suspected in control groups where five-eight-cell embryos present at day 2 were still at the same stage on day 3 but had developed further by day 4 . As this lag-phase occurs at about the stage of initiation of zygotic transcription, it is possible that these events are linked. Early transcription can be detected from only the eight-cell stage onwards in embryos produced in vivo (Camous et al., 1986; King et al., 1988). However, it appears that transcription could occur earlier in bovine embryos produced in vitro: tritiated uridine incorporation into neosynthesized RNA is detected at (a)

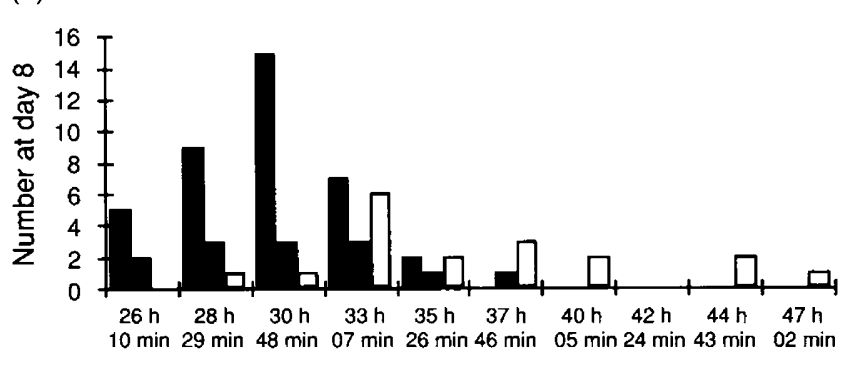

(b)

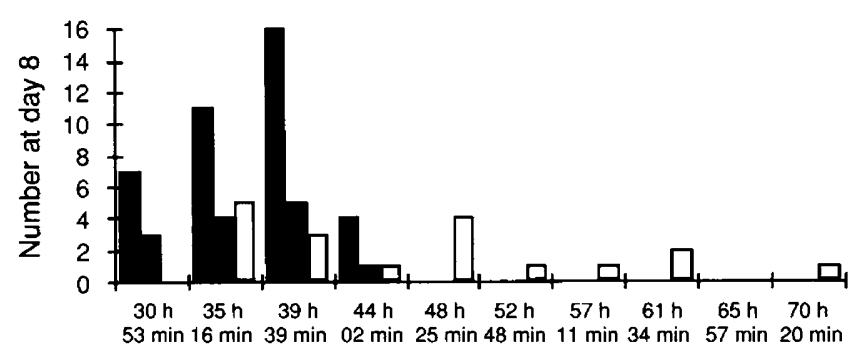

(c)

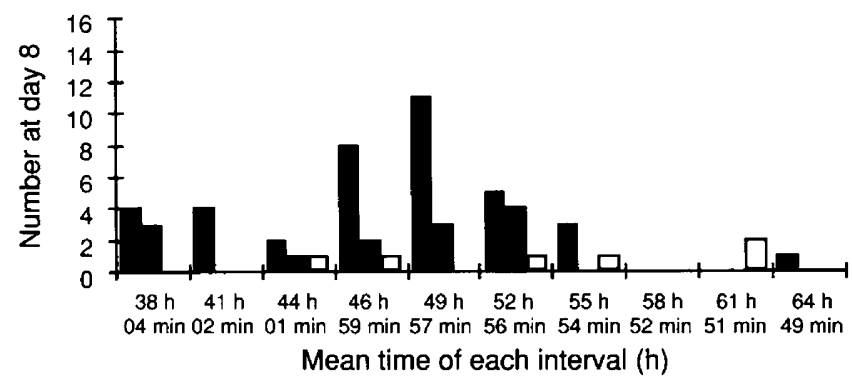

Fig. 3. Proportion of bovine morulae-blastocysts (black), 9-16-cell embryos (grey) and embryos with less than nine cells (white) at day 8 of culture, in relation to the time at which embryos in each category had reached (a) the two-cell stage $(n=69)$, (b) the three-four-cell stage $(n=69)$ and (c) the five-eight-cell stage $(n=57)$. The fastest dividing embryos are on the left while the slowest are on the right. Data are from movies 477 and 483 .

the two-cell stage but mainly in the five-eight-cell embryos (Plante and King, 1993; B. Grisart, A. Massip and F. Dessy, unpublished). 
The changes in nucleolar morphology associated with activation of rRNA synthesis at the four-eight-cell stage (King et al., 1989) and treatment with $\alpha$-amanitin to inhibit mRNA synthesis (Barnes and First, 1991) also support the theory that genome expression could start earlier in vitro. A link between transcriptional activity of the embryo and cleavage rate seems to be an important feature of early development, particularly between the four-cell and eight-cell stages that are known to be very sensitive to environmental conditions (Eyestone and First, 1991). First and Barnes (1989) put forward an interesting model linking cleavage rate with first genomic expression. Briefly, they state that 'the fixed transcriptional capacity of the early embryo may be the factor that lengthens the cell cycle by slowing the production of specific proteins needed for metaphase ... thus the lengthening of the cell cycle may allow for zygotic transcription to occur'. This model is supported by some results obtained in the frog (Kimelman et al., 1987), in which artificial lengthening of early cell cycles before the mid-blastula stage by inhibition of DNA replication induces premature expression of the genome.

A possible premature transcription resumption could result in unphysiological conditions that impair further development. Such a model would fit well with our observations: embryos that entered into lag-phase at the eight-cell stage (Table 3) gave more morulae and blastocysts than did those arrested at earlier stages (for example the five-cell and six-cell stages). Furthermore, embryos showing a lag-phase at the four-cell or five-cell stage cleaved more slowly than did those exhibiting a lag phase at the seven-cell or eight-cell stage. The first embryos reached their lag-phase stage after the second embryos had already reached more advanced stages.

The reasons for the lag-phase could be related to the amount or the quality of the RNA or the proteins stored in the oocytes. Some oocytes may have been harvested before the end of their growth phase. These would then be unable to develop to the eight-cell stage, resulting in a lengthening of the cell cycles. The lag-phase may be the manifestation of this deficiency, which could induce premature resumption of transcription. The fact that development in vitro of zygotes recovered in vivo is better than that of zygotes produced by maturation and fertilization in vitro suggests that oocytes ovulated in vivo are more competent than are those collected from ovaries from the abattoir (Van Soom and De Kruif, 1992). Suboptimal culture conditions could also have an influence on the lag-phase, but this would not explain why some embryos develop normally to the eight-cell stage and others do not. It is likely that both the status of the oocytes and culture conditions are involved in this phenomenon.

Some previous results (Plante and King, 1992; Van Soom et al., 1992) suggest that the first embryos to reach a given early cleavage stage have a greater chance of developing into morulae-blastocysts. The faster the embryos cleaved, the more chance (up to $70 \%$ ) they had of becoming morulae-blastocysts by day 8 . More slowly dividing embryos develop at a very low rate and reach only the 9-16-cell stage or even earlier stages.

In other experiments embryos were separated into fast, medium and slow cleaving at the two-cell, three-four-cell and five-eight-cell stage (B. Grisart, A. Massip and F. Dessy, unpublished). We obtained similar results: two-cell embryos selected $30 \mathrm{~h}$ after insemination, three-four-cell embryos selected $36 \mathrm{~h}$ after insemination and five-eight-cell embryos selected $48 \mathrm{~h}$ after insemination resulted in $47 \%, 38 \%$ and $43 \%$ becoming blastocysts, respectively. As morulae were not taken into account in these experiments, we assume that the percentage of morulae-blastocysts could have been higher. On the basis of these results a future experiment would be to preselect embryos that had reached the two-cell stage before 30-31 h after insemination in order to obtain a more homogeneous sample of embryos with a more predictable development. This may be very useful for the study of the regulation of early development (for example, expression of specific genes involved). It seems that differences in early development (for example, at the level of gene expression) result in variation in later development. Gene expression studies in heterogeneous embryo samples produced by fertilization in vitro could lead to some erroneous conclusions. Preselection as suggested above would allow the investigation of this hypothesis. The importance of the developmental competence of early bovine embryos in vitro has already been emphasized (Rieger et al., 1992). It would be particularly important to take this into account in such a study.

In conclusion, the cinematographic method is a useful tool for the study of early development of bovine embryos. (1) The kinetics of development was accurately established. (2) A developmental arrest (lag-phase) was observed during the third-cell cycle, which seems to be related to the ability of the embryo to develop up to the morula-blastocyst stage. (3) A clear relationship between the kinetics of early cleavage and further development was observed, allowing the selection of a more homogeneous embryo population in terms of its further developmental capacity.

This research was supported by grants from Ministère de l'Agriculture de la Région Wallonne de Belgique and from the biotechnology programme of the EC. B. Grisart is in receipt of a fellowship from the Institut pour l'Encouragement de la Recherche Scientifique dans l'Industrie et l'Agriculture. Our gratitude is expressed to J. F. Beckers for providing us with pure $\mathrm{p}-\mathrm{LH}$ and $\mathrm{p}-\mathrm{FSH}$ for oocyte maturation, to C. Boccart (Linalux, Belgium) for the supply of frozen bull semen, to the Centre-Audio-Visuel of Louvain-la-Neuve for making video copies of our movies and Sociéte des Abattoirs et des Marchés d'Anderlecht and Société Viangros for supplying cow ovaries.

\section{References}

Barnes FL and Eyestone WH (1990) Early cleavage and maternal zygotic transition in bovine embryos Theriogenology 33 141-152

Barnes FL and First NL (1991) Embryonic transcription in in vitro cultured bovine embryos Molecular Reproduction and Development 29 117-123

Bavister BD (1988) A minichamber device for maintaining a constant carbon dioxide in air atmosphere during prolonged culture of cells on the stage of an inverted microscope in vitro Cellular and Developmental Biology 24 759-763

Beckers J-F (1987) Isolation and use of a porcine FSH to improve the quality of superovulation in cattle Theriogenology 27213 (Abstract)

Bowman P and McLaren A (1970) Cleavage rate of mouse embryos in vitro and in vivo Journal of Embryology and Experimental Morphology 24 203-207

Camous S, Kopecny V and Fléchon J-E (1986) Autoradiographic detection of the earliest stage of $\left[{ }^{3} \mathrm{H}\right]$-Uridine incorporation into the cow embryo Biology of the Cell 58 195-200

Eyestone WH and First NL (1991) Characterisation of developmental arrest in early bovine embryos cultured in vitro Theriogenology 35 613-624 
First NL and Barnes FL (1989) Development of preimplantation mammalian embryos Progress in Clinical and Biological Research 294 151-170

Gordon I (1991) Potential application of cattle in vitro fertilization in commercial practice and research Embryo Transfer Newsletter 9 4-9

Hamilton WJ and Laing JA (1946) Development of the egg of the cow up to the stage of the blastocyst formation Journal of Anatomy 80 194-204

Iwasaki S, Yoshiba N, Ushijima U, Watanabe S and Nakahara T (1990) Morphology and proportion of inner cell mass of bovine blastocysts fertilized in vitro and in vivo Journal of Reproduction and Fertility 90 279-284

Kimelman D, Kirschner M and Scherson T (1987) The events of the midblastula transition in Xenopus are regulated by changes in the cell cycle Cell $\mathbf{4 8}$ 399-407

King WA, Niar A, Chartrain I, Betteridge KJ and Guay P (1988) Nucleolus organizer regions and nucleoli in preattachment bovine embryos Journal of Reproduction and Fertility $\mathbf{8 2} 87-95$

King WA, Chartrain I, Kopecny V, Betteridge KJ and Bergeron H (1989) Nucleolus organizer regions and nucleoli in mammalian embryos Joumal of Reproduction and Fertility Supplement 38 63-71

Lu KH and Polge C (1992) A summary of two years' results in large scale in vitro bovine embryo production Proceedings of the 12th International Congress of Animal Reproduction, The Hague 3 1315-1317

McGaugh JW, Olds D and Kratzer DD (1974) Ovum recovery in superovulated cows and cleavage rates in the fertilized ova Theriogenology $1213-217$

Massip A and Mulnard J (1980) Time-lapse cinematographic analysis of hatching of normal and frozen-thawed cow blastocysts Journal of Reproduction and Fertility 58 475-478

Massip A, Mulnard J, Van der Zwalmen P, Hanzen C and Ectors F (1982) The behaviour of cow blastocyst in vitro: cinematographic and morphometric analysis Joumal of Anatomy 134 399-405

Massip A, Van der Zwalmen P and Zwijsen W (1983a) Atypical hatching of a cow blastocyst leading to separation of complete twin half blastocysts Veterinary Record 112301

Massip A, Zwijsen W and Mulnard J (1983b) Cinematographic analysis of the cleavage of the cow egg from the 2-cell to 16-cell stage Archives de Biologie $9499-106$

Mermillod P, Mourmeaux J-L, Wils C, Massip A and Dessy F (1992a) Proteinfree-conditioned medium for complete bovine embryo development Veterinary Record 13013
Mermillod P, Wils C, Massip A and Dessy F (1992b) Collection of oocytes and production of blastocysts in vitro from individual, slaughtered cows Journal of Reproduction and Fertility 96 717-723

Mermillod P, Vansteenbrugge A, Wils C, Mourmeaux J-L, Massip A and Dessy F (1993) Characterization of embryotrophic activity of exogenous protein-free oviduct-conditioned medium used in culture of cattle embryos Biology of Reproduction $49582-587$

Mulnard JG (1967) Analyse microcinématographique du developpement de l'oeuf de souris du stade II au stade blastocyste Archives de Biologie 78 107-138

Plante L and King WA (1992) Effect of time to first cleavage on hatching rate of bovine embryo in vitro Theriogenology 37274 (Abstract)

Plante L and King WA (1993) Developmental potential of spontaneously activated bovine oocytes Theriogenology 39286 (Abstract)

Pollard JW, Scodras JM, Plante L, King WA and Betteridge KJ (1991) Definition of the cleavage stage(s) at which oviducal epithelial cells enable bovine embryos to pass through the in vitro 8-16-cell block Theriogenology 35256 (Abstract)

Prather RS and First NL (1988) A review of early mouse embryogenesis and its application to domestic species Joumal of Animal Science 66 2626-2635

Rieger D, Loskutoff NM and Betteridge KJ (1992) Developmentally related changes in the metabolism of glucose and glutamine by cattle embryos produced and co-cultured in vitro Journal of Reproduction and Fertility 95 $585-595$

Sirard MA and Lambert RD (1985) In vitro fertilization of bovine follicular oocytes obtained by laparoscopy Biology of Reproduction 33 487-494

Thibault C (1966) La culture in vitro de l'oeuf de vache Annales de Biologie Animale, Biochimie, Biophysique 6 159-164

Van Soom A and De Kruif A (1992) A comparative study of in vivo and in vitro derived bovine embryos Proceedings of the 12th International Congress of Animal Reproduction, The Hague 3 1363-1365

Van Soom A, Van Vlaenderen I, Mahmoudzadeh AR, Deluyker H and De Kruif A (1992) Compaction rate in in vitro fertilized bovine embryos related to the interval from insemination to first cleavage Theriogenology 38 905-919 